\title{
BRONZKORI SARLÓK VÁLTOZATOS SZEREPEKBEN
}

\section{FejÉr EszTER ${ }^{1}$}

Magyar Régészet 9. évf. (2020), 4. szám, pp. 22-29. doi: https://doi.org/10.36245/mr.2020.4.1

A bronzsarlók a késö bronzkori Európa egyik legnagyobb számban feltárt tárgytípusát alkotják, a Kárpát-medencében pedig különösen nagy mennyiségben fordulnak elö. Mivel formájuk évezredek alatt alig változott, egyszerü alakjuk és hétköznapinak vélt funkciójuk miatt sokáig a kutatók figyelmét sem keltették fel. Elökerülési körülményeik és állapotuk alaposabb vizsgálata, valamint ezen adatok történeti, néprajzi vagy antropológiai megfigyelésekkel való összevetése ugyanakkor rávilágit arra, hogy a bronzkori emberi számára nagyobb jelentőséggel, szerteágazóbb jelentéstartalommal és különlegesebb értékkel bírhattak.

\section{A SARLÓK KIALAKULÁSA}

A modern sarlók legrégebbi ősei egyidősek a mezőgazdaság kialakulásával, a termesztett növények megjelenésével, bár fontos megjegyezni, hogy már az ezt megelőző időszakban is gyüjtöttek, vágtak vad gabonaféléket. Az első olyan kőeszközök, amelyeket a rajtuk megfigyelhető kopásnyomok alapján biztosan gabona aratására használtak, a Közel-Keletről, a Kr. e. 10. évezred előttről ismertek (ANDERSON 1999). Európában a legrégebbi kézi aratószerszámok a Kr. e. 6. évezredből származnak. Ezek általában egy vagy több kisebb-nagyobb kőpengéből álltak, amelyeket egy fából kialakított nyélbe illesztve használtak. Ilyen típusú eszközök a neolitikumtól a késő bronzkorig használatban voltak, egy ideig még valószínüleg a fémpengék elterjedése után is megmaradtak (Behm-Blancke 1963; Horváth, KozÁk \& Pető 2001, 199-200; PALOMO et al. 2011). A kőpengékkel ellentétben a fémböl készült eszközök esetében nem állnak rendelkezésünkre olyan vizsgálati módszerek, amelyek segítségével meghatározhatnánk, hogy valóban gabonát arattak-e velük, így esetükben azokat a tárgyakat nevezzük sarlónak, amelyek - kizárólag formai alapon - íves kézi vágóeszköznek tünnek.

Bronzsarlók, azaz bronzból készített íves sarlópengék a Kárpát-medencében a középső bronzkorban (a Kr. e. 2. évezred első felében) jelentek meg először, majd csaknem ezer éven át szinte változatlan formában gyártották és használták őket. A bronzkori Európa különböző régióiból többféle típust is ismerünk, amelyek között a fö különbség a pengék végének a kialakításában, azaz nyelezési technikájában rejlik (1. kép). Magyarország területén két fö típust öntöttek: gombos végü és nyélnyújtványos sarlókat. A gombos végű sarlók szinte csak egy pengéből állnak, amelynek végén egy, a penge síkjából kiálló gomb segítette a szerves anyagból készült nyél rögzítését (2.b kép). Ezzel szemben a nyélnyújtványos típusú sarlók pengéje egy, a penge síkjától nem elváló, ahhoz

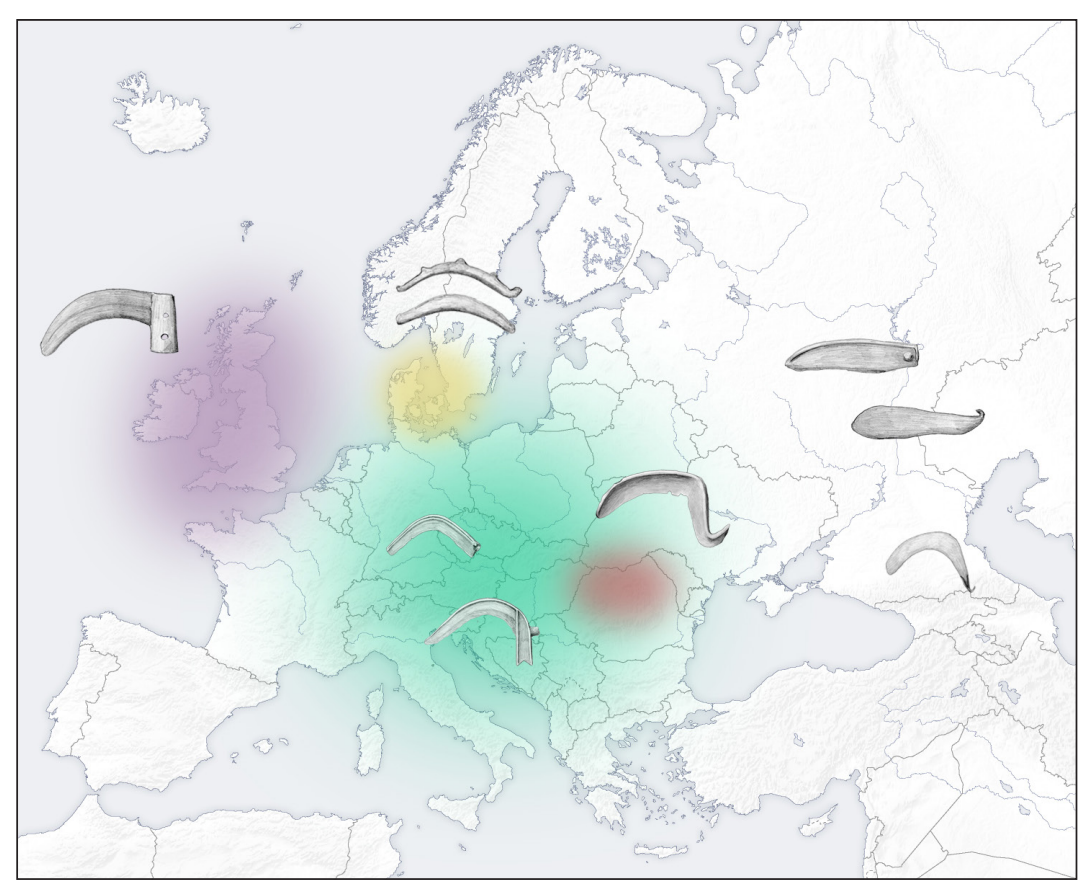

1. kép. A legfontosabb bronz sarlótípusok elterjedése Európában (grafika: Fejér Eszter) 
Fejér Eszter • Bronzkori sarlók változatos szerepekben

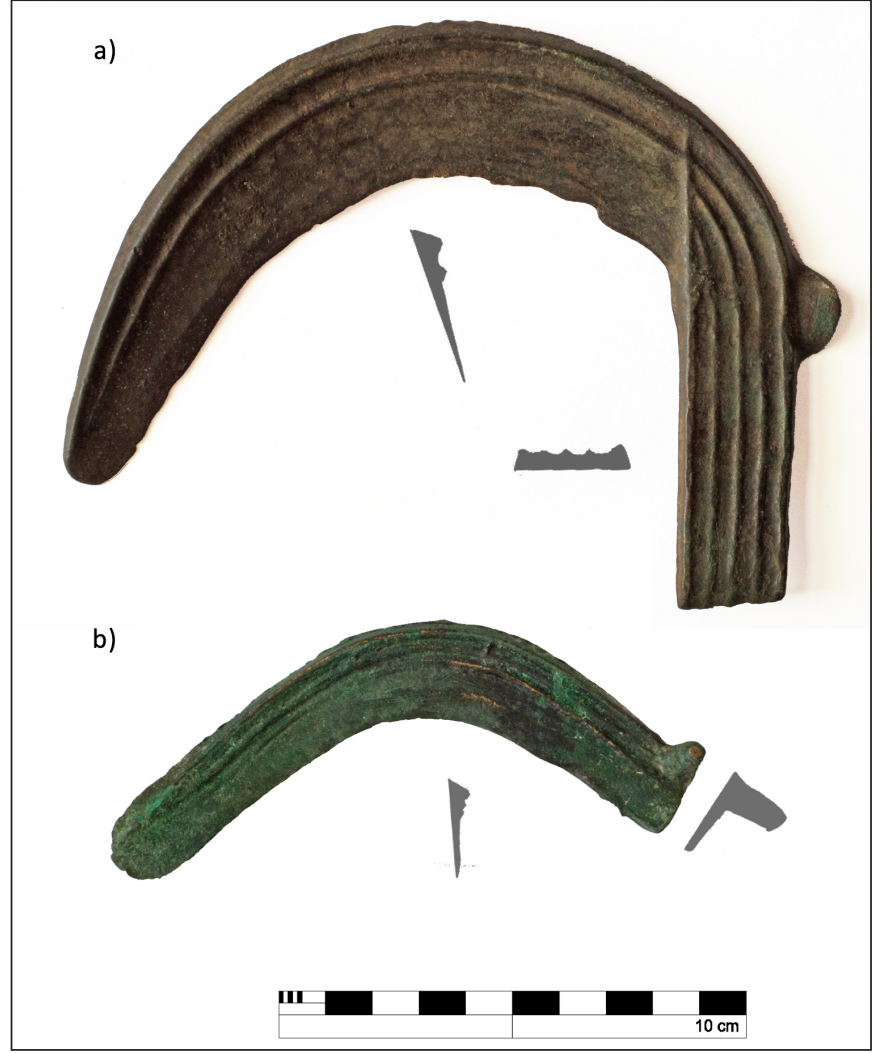

2. kép. Bronzkori nyélnyújtványos és gombos sarló (Törökkoppány, Szikszó) (fotó: Fejér Eszter; RRM Kaposvár, ltsz.: 3927; HOM Miskolc, ltsz.: 66.14.4)

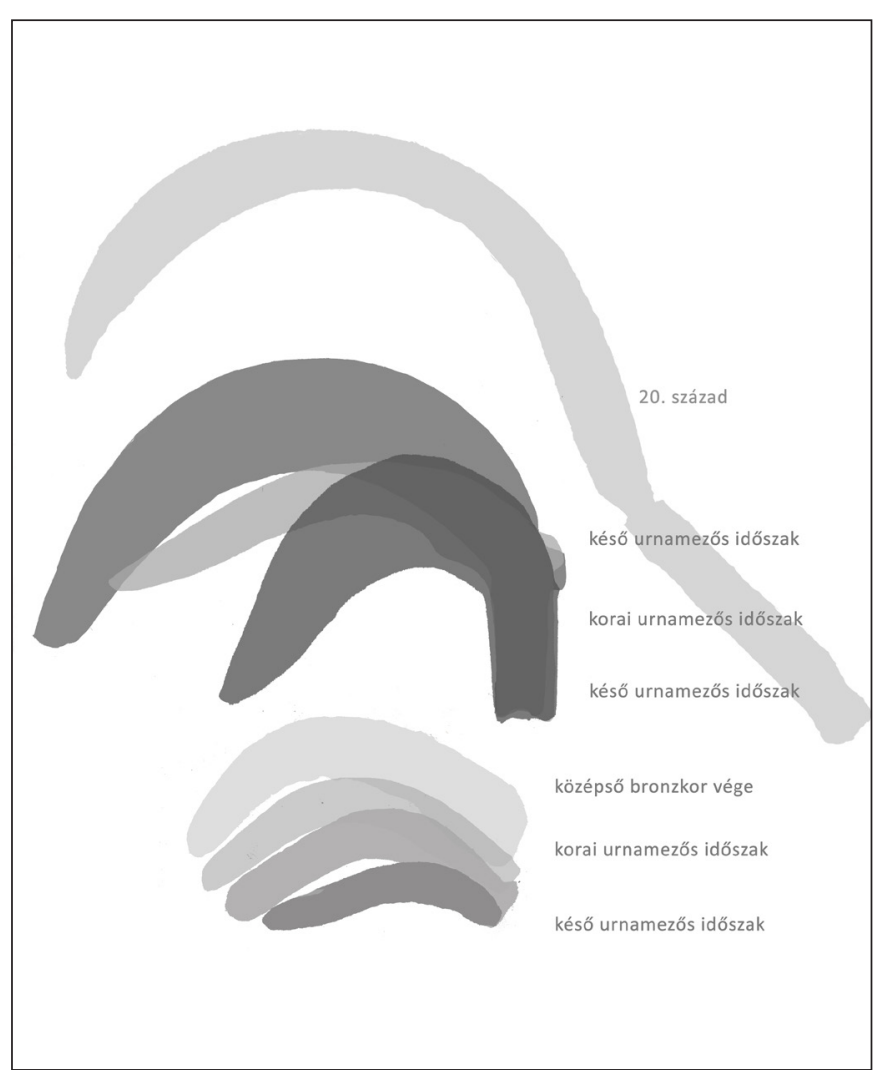

3. kép. A bronzsarlók méretének változása az egyes korszakokban (grafika: Fejér Eszter)

közel 90 fokban csatlakozó nyújtvánnyal egészül ki, ami a nyél teljesen más típusú rögzítését tette lehetővé (2.a kép). Bár gombos végü és nyélnyújtványos sarlók sokszor egymás társaságában kerülnek elő, a két sarlótípus elterjedési súlypontja némileg eltér a Kárpát-medencében. A nyélnyújtványos darabok a teljes területről ismertek, a gombos végü típus a Dunántúlon és az attól délnyugatra fekvő területeken csaknem teljesen hiányzik. A pengék átlagosan 10-13 cm (gombos végü sarlók) és 15-18 cm (nyélnyújtványos sarlók) távolságot fognak át, de a bronzkor vége felé méretük egyértelmüen csökkent, illetve ekkor kísérleti jelleggel nagyobb és egyedi bronzsarlók is megjelentek a leletanyagban (3. kép).

A bronzból készült sarlópengéket a kora vaskor időszakában kezdték el felváltani a vasból készített darabok, a késő vaskor folyamán pedig megjelentek az első olyan vassarlók, amelyek az azt követő kétezer év sarlótípusait is meghatározták. Ezek kialakításuk és nyelezésük tekintetében alig különböznek már a ma is ismert eszközöktől (MÜLler 1982; STEENSBERG 1943, 133-247).

\section{ELREJTETT KINCSEK, REJTÉLYES JELRENDSZEREK?}

A bronzkori fémtárgyak között a sarlók mennyiségük folytán kiemelkedő helyet foglalnak el. A Kárpátmedence területéről jelenleg több mint 12000 bronzsarlót ismerünk, amelyek szinte kizárólag elrejtett tárgyegyüttesekből, úgynevezett depókból kerültek elö. Az ilyen kincsleletek létrejöttének, elrejtésének okai és körülményei változatosak lehettek, a szakirodalomban erre vonatkozóan többféle magyarázattal is találkozhatunk (összefoglalóan pl. HANSEN 2013; V. SzABÓ 2019). Temetkezések mellékleteként csak a halomsíros kultúra és a Piliny-, illetve Kyjatice-kultúrák elterjedési területén találkozhatunk velük. Településeken pedig ritkán és jórészt csak szórványleletekként kerülnek felszínre, amelyeknek elsődleges kontextusáról nem rendelkezünk információval. Az ismert bronzkincseknek legalább kétharmada tartalmaz sarlót, azoknak általánosan kedvelt tárgytípusai voltak, de a deponált tárgyakon belüli arányuk kismértékben korszaktól és területtől függő. A leglátványosabbak a korai urnamezős időszak (Kr. e. 13-11. század) dunántúli együttesei, amelyek akár több száz bronzsarlót is magukban foglaltak (4. kép). Ezekbe a depókba a sarlókat használt, 
Fejér Eszter • Bronzkori sarlók változatos szerepekben

de még nem teljesen elhasznált állapotban, viszont sokszor - a korszakra jellemző módon - szándékosan megrongálva, meghajlítva, összetörve helyezték el. Ezzel szemben a későbbi időszakokban (fiatalabb urnamezős időszak, Kr. e. 11-10. század) a sarlókat kisebb számban és gyakran még újonnan, használat elött rejtették el (FEJÉR 2017).

A korai urnamezős időszak sarlói nemcsak nagy számuk, hanem a rajtuk látható plasztikus jelek miatt is különlegesek. Közép-Európában elsősorban az ott gyakori gombos sarlókon figyelhetők meg plasztikus bordák, Magyarország területén viszont leginkább nyélnyújtványos sarlókon, a sarlók nyújtványán különböző alakzatokba rendezve találkozhatunk velük. Míg a penge tetején, a nyélnyújtvány szélén és esetleg közepén futó függőleges bordák kialakítása magyarázható praktikus okokkal (pl. a nyél stabilitásának biztosítása), a bonyolultabb elrendezésekre nehéz funkcionális magyarázatot találni. Sőt, mondhatni mind a tárgy öntését, mind a nyelezését nehezítette ez a megoldás. Ráadásul, mivel a sarló szerves anyagból készült nyele használat közben elfedte ezt a részt, a bordáknak pusztán esztétikai szerepe is kétségbe vonható. A különféle elemekböl felépülö alakzatoknak számtalan variációja ismert (5. kép), a sarlók döntő többsége mégis csupán kevesebb, mint tíz kombináció egyedileg módosított változatát képviseli (SOMMERfeld 1994; WANZEK 2002; JAHN 2013). A bordákból összeálló minták értelmezése máig a késő bronzkor egyik nagy rejtélye. Hasonló jelek sarlókon kívül más tárgyakról nem, vagy alig ismertek, talán csak a tokos balták plasztikus elemei

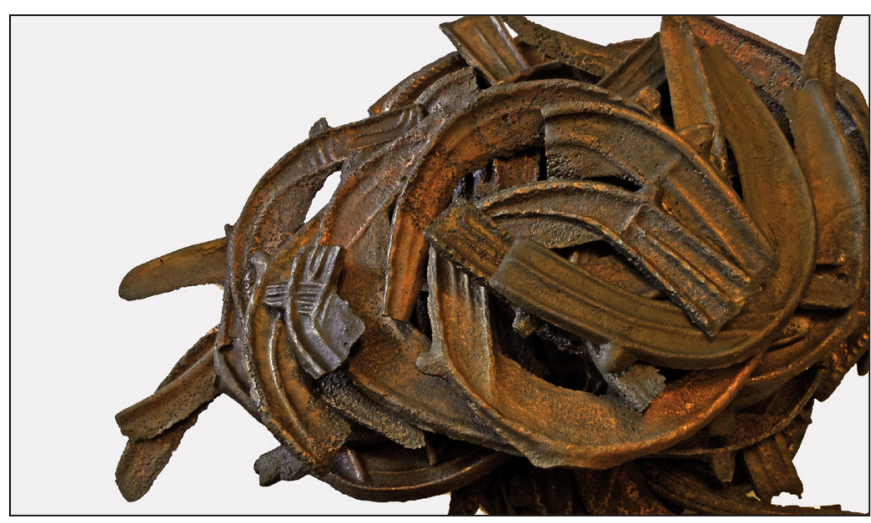

4. kép. A több mint 60 sarlót tartalmazó bakócai depó részlete (fotó: Fejér Eszter; Janus Pannonius Múzeum, Pécs, ltsz. 69.22.1-13)

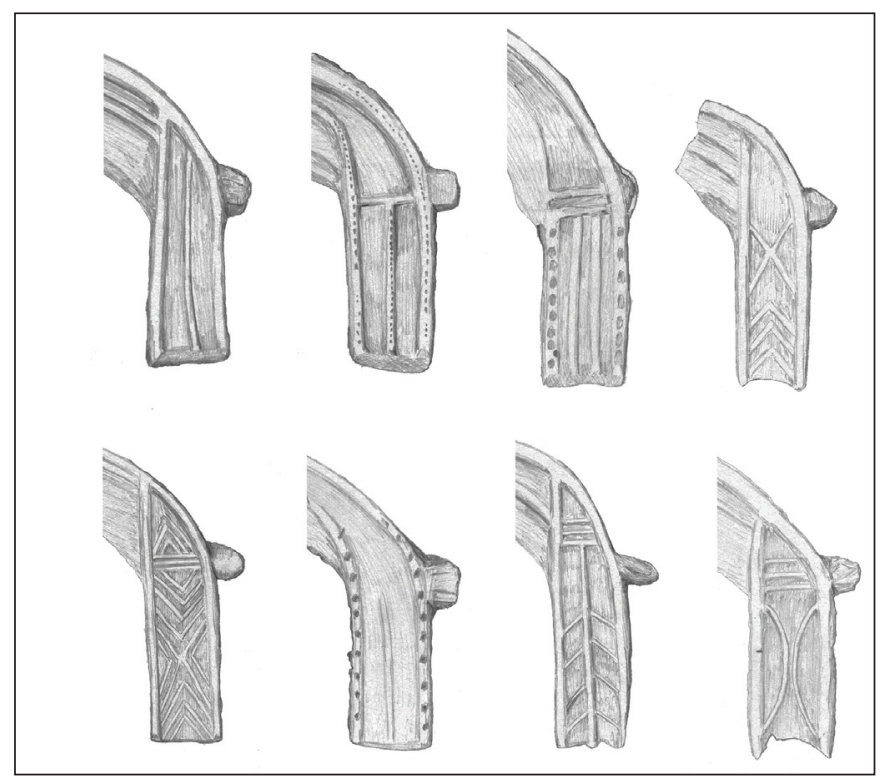

5. kép. Különbözö elrendezésü bordák nyélnyújtványos sarlókon (Balatonkiliti, Öreglak) (rajz: Fejér Eszter) hasonlítanak rájuk. A mintákat többen próbálták „megfejteni”, jelrendszerként értelmezni, de nincs olyan általánosan elfogadott magyarázat, amely minden kétséget kizáróan választ adna arra a kérdésre, hogy miért voltak a bordák egy megközelítőleg 200 éves időszakban kanonizált elemei a bronzsarlóknak.

\section{ARATÓESZKÖZÖK, FEGYVEREK, MÁGIKUS EREJÜ TÁRGYAK}

A bronzsarlónak tartott tárgyak funkciójának meghatározásához természettudományos vizsgálatokból származó adatokra és korabeli írásos forrásokra nem támaszkodhatunk, de a tárgyakon megfigyelhető megmunkálási és használati nyomokat, illetve a néprajzi, történeti és antropológiai analógiákat egyaránt segítségül hívhatjuk.

Az itt tárgyalt fémleleteket elsősorban formájuk determinálja aratóeszközként való azonosításra, elsődleges mezőgazdasági funkciójukat aligha lehet kétségbe vonni. A késő bronzkortól kezdve minden bizonynyal ezeket a fémpengéket használták a kőből készült sarlók helyett (és részben mellett) a gabona és más termények betakarítására, de a feltehetően regionálisan és időben is változó egykori aratási technikák megértéséhez kevés támponttal szolgálnak. Az aratás időpontjára, a vágás magasságára, a learatott növényfajtákra paleobotanikai adatokból következtethetünk, az így nyert információk ugyanakkor csak lokálisan érvényesek (Gyulai 2010; BouBy 2003; BeranovÁ 1991; 1993). A bronzsarlók használatának pontos tech- 


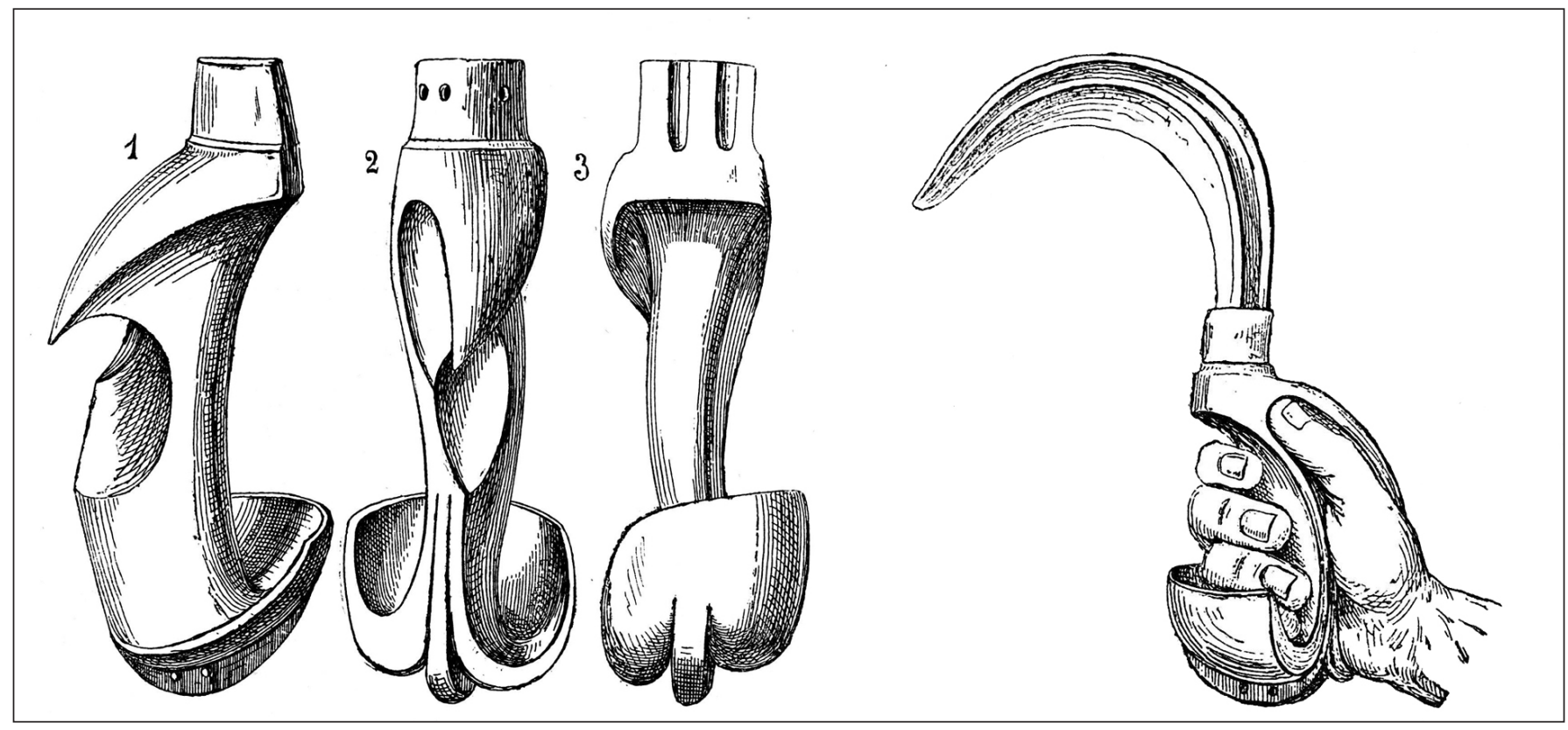

6. kép. Svájcban talált fából készitett bronzkori sarlónyél (nyélnyújtványos típushoz) (Mörigen; Keller 1873 alapján)

nikája alig ismert, mivel a fémpengékhez tartozó nyelek nagyon ritkán kerültek elő. Csak néhány nyugateurópai lelet tanúskodik arról, hogy hogyan nézhettek ki: 15-20 cm hosszú, többnyire ergonomikus kialakítású fanyelekbe illesztették a pengéket (6. kép) (BRYSBAerT 1998; Egloff 1984; Primas 1986, 195-196). Az a késő bronzkor legvégén egész Európában tetten érhető tendencia, miszerint a bronzsarlók mérete lecsökkent, talán az egyetlen olyan, a sarlókhoz köthető megfigyelés, amely az adott korszakban végbement mezőgazdasági változásokra, a sürübb vetés elterjedésére utal (JAHN 2013, 86-87; SCHLICHTHERLE 1992, 37). A méretcsökkenés hátterében azonban más magyarázatok is állhatnak.

Mivel más ívelt pengéjü, vágásra alkalmas eszközt a késő bronzkorból nem ismerünk, adódik, hogy a sarlóként meghatározott tárgyaknak univerzális vágóeszköz funkciót tulajdonítsunk, amelyeket nem csak aratásra, de ha a szükség úgy kívánta, más mezőgazdasági és háztáji feladatokra is felhasználhattak. A szőlőmetszés, ágvágás, vesszőszedés, valamint a fa- és bőrmegmunkálás néprajzi korú szerszámai között gyakran találkozunk hasonlóan hajlított pengéjü tárgytípusokkal (pl. TAKÁCs 1967; EÖRY 1999), melyek funkcióját a késő bronzkorban a bronzsarlók láthatták el. Az egyes sarlópengeformákat és nyelezési technikákat, noha korábban ezt feltételezték, nem tudjuk egyértelmüen adott feladatokhoz, tevékenységtípusokhoz kötni.

A mezőgazdasági funkció mellett a sarlókat, mint azt több középkori és kora újkori forrás is szemlélteti, fegyverként is használhatták. Egy 16. századi vívómester, Paulus Hector Mair által összeállított vívó kézikönyv, a De arte athletica számos, a korszakban ismert harcmüvészeti technikát mutat be, leírva és illusztrálva a bevethető fegyverek típusait és használati módját. A mü egyik fejezete a sarlókkal való küzdelmet részletezi (Paulus Hector Mair, De arte athletica, I. kötet, G fejezet) (7. kép). Bár a sarlókra valószínüleg elsősorban sosem fegyverként tekintettek, a történelem folyamán számos példát láthattunk ilyen jellegü, ad hoc felhasználásukra. Elterjedt elképzelés, hogy az európai parasztfelkelések idején, amikor a helyzet megkövetelte, a földmüvesek gyakorta mezőgazdasági szerszámokkal, például sarlókkal fegyverezték fel magukat (Demmin 1869, 447-450; GeréB 1950, 132, 142). A Távol-Keletről, ahol a sarlók, illetve sarló alakú vágóeszközök hagyományosan szintén a paraszti munka eszköztárához tartoztak, ugyancsak számos analógiát ismerünk a paraszti fegyverkezésben játszott szerepükkel kapcsolatban, és ezen a területen lényegében mind a mai napig megmaradtak ilyen funkcióikban is (vö. többek között: a kama és kusarigama Japánban, a karambit Malajziában). A fentiek alapján nem kizárt, hogy adott esetben a Kárpát-medencei bronzkori sarlókat is használhatták harci helyzetben, bár erre utaló egyértelmü bizonyítékot (például összetüzésből eredő sérüléseket a pengéken) a több ezer magyarországi lelet vizsgálata során egy esetben sem sikerült megfigyelni. 


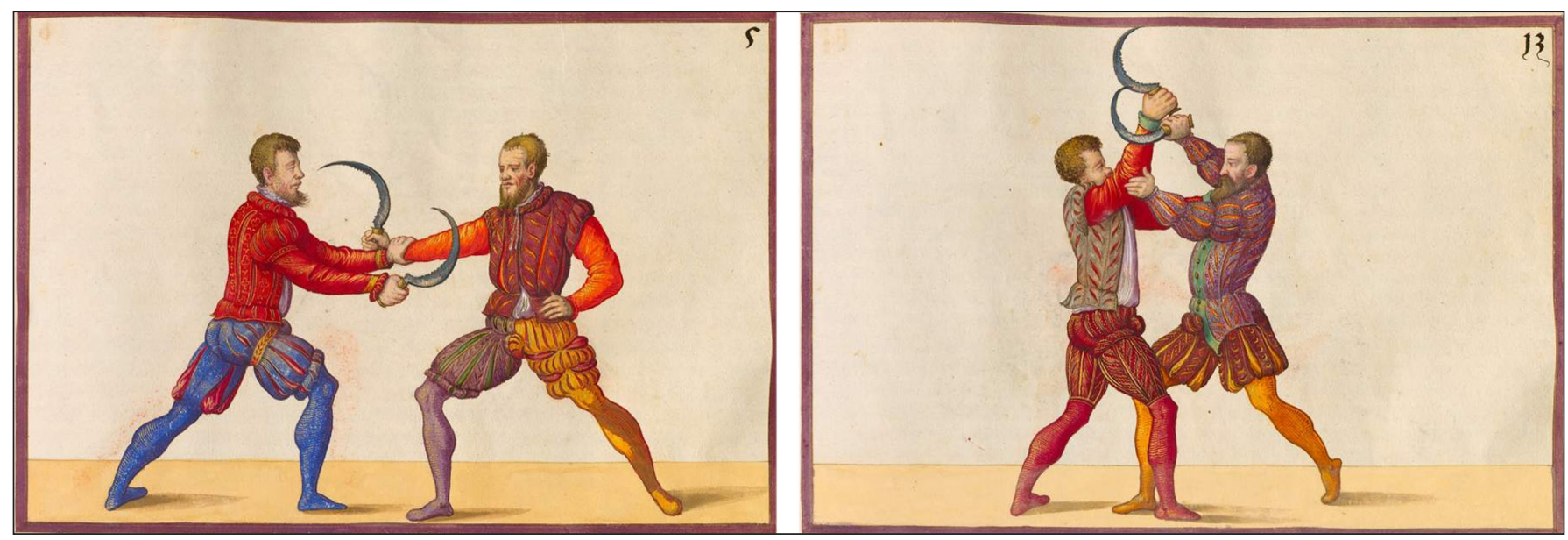

7. kép. Küzdelem sarlóval a 16. században, Paulus Hector Mair illusztrációi (Paulus Hector Mair, De arte athletica (16. század). Cod. icon. 393, Bayerische Staatsbibliothek, München; forrás: http://daten.digitale-sammlungen.de/bsb00006570/ image_459; http://daten.digitale-sammlungen.de/bsb00006570/image_467. Letöltés: 2020.11.03.)

A sarlók szerepét érintő, a Kárpát-medencei bronzkori leletekhez térben és időben legközelebb álló írott hagyomány a klasszikus kori görög-római forrásokból maradt ránk. Az ókori görög források bár ritkán tesznek említést sarlókról, de ha mégis, akkor azok különleges szerepkörben, mitológiai történetek részeként tünnek fel: olyan eszközök voltak, amelyeket a mitikus hösök félelmetes lények, szörnyetegek legyőzéséhez használtak. Kronosz egy az anyjától, Gaiától kapott sarlóval kasztrálta apját, Uránoszt, majd átvette töle a világ feletti hatalmat (Hésziodosz, Theogonia 162, 179). Egy hagyomány szerint ugyancsak egy isteni sarló segítette Perszeuszt, aki az Athénétől kapott ajándék segítségével vágta le a dermesztő tekintetű Medusza fejét (Apollodórosz, Bibliothéké 2.4.2.) (8. kép). A két híresebb történeten kívül más mítoszokban is találkozhatunk még sarlókkal, általában mint különleges erővel bíró fegyverekkel (pl. Euripidész, Ión 192, Ovidius, Metamorphoses 1.717). Egyes szövegek nem fegyverként, hanem mágikus összefüggésben említik őket: több antik szerző is leírta, hogy a Fekete-tenger keleti partvidékén élő híres ókori varázslónő, Médeia éjjelente egy bronzsarlót használt bizonyos növények levágására, míg idősebb Plinius szerint a kelta mitológiában a druidák arany sarlóval metszették le a fagyöngyöt (KRON 1998, 213; Plinius maior, Naturalis historia XVI.95).

Bár az ókori Hellász és a római világ régészeti anyagában ritkán szerepelnek kitüntetett helyen a sarlók, lelőhelyük néha itt is utal mezőgazdasági szerepükön túlmutató, nem szokványos, rituális használatukra. Több görög szentélykörzetben (pl. perakhórai Héraion, déloszi Artemiszion) is megfigyelték, hogy a Kr. e. 8. századtól kezdve sarlókat is deponáltak (SCHIERING 1968, 157-158; KRON 1998, 195-201). A spártai Artemisz-Orthia szentélyben pedig a Kr. e. 4. századtól kezdve az ott rendezett egyik verseny ifjú győztesei jutalmul vassarlókat kaptak, amelyeket kősztélékre rögzítve ajánlottak fel az istennőnek (WOODWARD 1929).

Bár ezek a szórványos antik példák egyáltalán nem jelentik azt, hogy a sarlókra a bronzkorban vagy a vaskorban varázserővel bíró tárgyakként tekintettek, arra rávilágítanak, hogy szimbolikus jelentőségük nagyobb lehetett, mint ahogy azt a 21 . században képzeljük. A mezőgazdasági tevékenységek az őskorban feltehetően jóval ritualizáltabb keretek között zajlottak, a modern kori felfogással

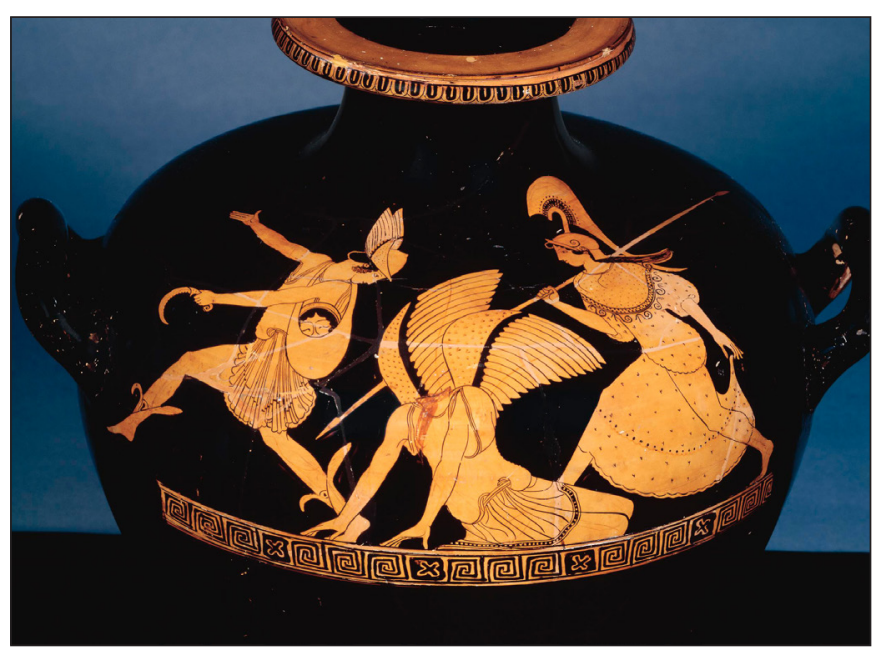

8. kép. Perszeusz (balra) kezében a sarlóval, miután levágta Medusza fejét (athéni vörösalakos hüdria, Kr. e. 460 körül) (C) The Trustees of the British Museum; British Museum, London; 1873, 0820.352) 
Fejér Eszter • Bronzkori sarlók változatos szerepekben

ellentétben ezek vallási-szakrális oldala, nem evilági hatalmakhoz füződő, vélt kapcsolata az akkori ember számára jóval hangsúlyosabb lehetett. A vetést, aratást és ezek eszközeit még a 20. században is több hiedelem, népszokás övezte, illetve övezi ma is. Ezért a bronzkori sarlókon található jelek, nagyszámú deponálásuk, vagy használatlan állapotban való elrejtésük megértéséhez is talán az egykor hozzájuk kapcsolódó szimbolikus jelentések feltárása vihet közelebb.

\section{KÖSZÖNETNYILVÁNITTÁS}

A tanulmány a Freie Universität Berlin Ösrégészeti Intézetében írt doktori disszertáció anyagából készült (FEJÉr 2020). A kutatást 2014-2017 között az Elsa Neumann Stipendium des Landes Berlin ösztöndíjprogram támogatta.

\section{AjÁNLOTT IRODALOM}

Cappers, R. T. J., Neef, R., Bekker, R. M., Fantone, F. \& Okur, Y. (2016). Digital Atlas of Agricultural Practices and Food Processing. Groningen Archaeological Studies 30. Eelde: Barkhuis, Groningen University Library.

Schmidt, H. (1904). Der Bronzesichelfund von Oberthau, Kr. Merseburg. Zeitschrift für Ethnologie 36 (III-IV), 416-452.

Selmeczi Kovács, A. (2006). A kézi aratás járulékos eszközei. The Auxiliary Implements of Manual Harvesting. Catalogi Musei Ethnographiae 11. Budapest: Néprajzi Múzeum.

Steensberg, A. (1943). Ancient Harvesting Implements: A Study in Archaeology and Human Geography. Nationalmuseets skrifter 1. København: Gyldendalske Boghandel, Nordisk forlag.

\section{BIBLIOGRÁFIA}

Anderson, P. C. (1999). Experimental Cultivation, Harvest, and Threshing of Wild Cereals. In P. C. Anderson (ed.), Prehistory of Agriculture. New experimental and Ethnographic Approaches (pp. 118-144). Monograph 40. Los Angeles: Institute of Archaeology, University of California, Los Angeles.

Behm-Blancke, G. (1963). Bandkeramische Erntegeräte. Alt-Thüringen 6, 104-175.

Beranová, M.(1991). Archäologie und Botanik aus der Sicht des Archäologen (Anbau von Kulturpflanzen). In E. Hajnalová (ed.), Palaeoethnobotany and Archaeology. International Work-Group for Palaeoethnobotany 8th Symposium, Nitra-Nové Vozokany 1989 (pp. 37-50). Acta Interdisciplinaria Archaeologica VII. Nitra: Archaeological Institute of the Slovak Academy of Sciences.

Beranová, M. (1993). Versuche zur vorgeschichtlichen und frühmittelalterlichen Landwirtschaft. Památky Archeologické 84 (1), 97-119.

Bouby, L. (2003). Harvesting cereals with bronze sickles in Bronze Age Southern France. Antiquity Project Gallery 77 (296), http://www.antiquity.ac.uk/projgall/bouby296/ (Letöltés: 2020.11.03.) 
Fejér Eszter • Bronzkori sarlók változatos szerepekben

Brysbaert, A. (1998). A Late Bronze Age sickle from Shinewater Park: The treatment of a waterlogged composite. Journal of Conservation and Museum Studies 4 (1), 1-5. http://doi.org/10.5334/jcms.4981

Demmin, A. (1869). Die Kriegswaffen in ihrer historischen Entwicklung von der Steinzeit bis zur Erfindung des Zündnadelgewehrs: ein Handbuch der Waffenkunde. Leipzig: E. A. Seemann.

Egloff, M. (1984). A l'aube du „design”: les manches de faucilles du Bronze final. Helvetia Archaeologica 15 (57-60), 51-66.

Eőry, B. (1999). A tokosbalta, mint sokrétű munkaeszköz. Das Tüllenbeil, als vielseitiges Arbeitsgerät. Savaria 24 (3), 437-446.

Fejér, E. (2017). Technologische Angaben zur Deutung der Sicheln in spätbronzezeitlichen Horten. In G. Kulcsár, G. V. Szabó, V. Kiss \& G. Váczi (eds.), State of Hungarian Bronze Age Research. Proceedings of the conference held between 17th and 18th of December 2014 (pp. 337-343). Ösrégészeti Tanulmányok / Prehistoric Studies 2. Budapest: Institute of Archaeology, Research Centre for the Humanities, Hungarian Academy of Sciences - Institute of Archaeological Sciences, Faculty of Humanities, Eötvös Loránd University - Ösrégészeti Társaság / Prehistoric Society.

Fejér, E. (2020). Die Sicheln im Kulturinventar der Bronzezeit (Doktori disszertáció). Freie Universität Berlin, Fachbereich Geschichts- und Kulturwissenschaften, Berlin.

Geréb, L. (1950). A magyar parasztháborúk irodalma 1437-1514. Budapest: Hungária Könyvkiadó.

Gyulai, F. (2010). Archaeobotany in Hungary. Archaeolingua Series Maior 21. Budapest: Archaeolingua.

Hansen, S. (2013). Bronzezeitliche Deponierungen in Europa nördlich der Alpen. Weihgaben ohne Tempel. In I. Gerlach \& D. Raue (eds.), Sanktuar und Ritual. Heilige Plätze im archäologischen Befund (pp. 371-387). Menschen - Kulturen - Traditionen 10. Rahden, Westf.: Leidorf.

Horváth, T., Kozák, M.\& Pető,A. (2001). Adatok a bronzkori kőeszközök kutatásához (SzázhalombattaFöldvár bronzkori rétegeinek kőanyaga). Factual Information for Researching Bronze Age Stone Instruments (The Stone Find of the Százhalombatta-Földvár Bronze Age Stratum). In J. Dani, Zs.

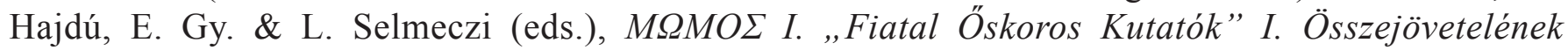
konferenciakötete. Debrecen 1997. november 10-13 (pp. 199-215). Debrecen: Debreceni Déri Múzeum Kiadványai.

Jahn, C. (2013). Symbolgut Sichel. Studien zur Funktion spätbronzezeitlicher Griffzungensicheln in Depotfunden. Universitätsforschungen zur Prähistorischen Archäologie 236. Bonn: Habelt.

Keller, F. (1873). Handgriff der Bronzesichel. Anzeiger für schweizerische Altertumskunde 6 (2), $422-424$.

Kron, U. (1998). Sickles in Greek Sanctuaries: Votives and Cultic Instruments. In R. Hägg (ed.), Ancient Greek Cult Practice from the Archaeological Evidence. Proceedings of the Fourth International Seminar on Ancient Greek Cult, organised by the Swedish Institute at Athens, 22-24 October 1993 (pp. 187-215). Stockholm: Åströms Förlag.

Müller, R. (1982). A mezögazdasági vaseszközök fejlödése Magyarországon a késővaskortól a törökkor végéig. Zalai Gyüjtemény 19. Zalaegerszeg: Zala Megyei Levéltár. 
Fejér Eszter • Bronzkori sarlók változatos szerepekben

Palomo, A., Gibaja, J. F., Piqué, R., Bosch, A., Chinchilla, J. \& Tarrús, J. (2011). Harvesting cereals and other plants in Neolithic Iberia: The assemblage from the lake settlement at La Draga. Antiquity 85, 759-771. https://doi.org/10.1017/S0003598X00068290

Primas, M. (1986). Die Sicheln in Mitteleuropa I (Österreich, Schweiz, Süddeutschland). Prähistorische Bronzefunde XVIII/2. München: Beck.

Schiering, W. (1968). Landwirtschaftliche Geräte. In W. Richter (ed.), Die Landwirtscahft im homerischen Zeitalter (pp. 147-158). Archaeologia Homerica 2. Göttingen: Vandenhoeck \& Ruprecht.

Schlichtherle, H. (1992). Jungsteinzeitliche Erntegeräte am Bodensee. Plattform 1, 24-44.

Sommerfeld, C. (1994). Gerätegeld Sichel. Studien zur monetären Struktur bronzezeitlicher Horte im nördlichen Mitteleuropa. Vorgeschichtliche Forschungen 19. Berlin, New York: de Gruyter.

Steensberg, A. (1943). Ancient Harvesting Implements: A Study in Archaeology and Human Geography. Nationalmuseets skrifter 1. København: Gyldendalske Boghandel, Nordisk forlag.

Takács, L. (1967). Kaszasarlók Magyarországon. Sensensicheln in Ungarn. Ethnographia 78 (1), 1-21.

V. Szabó, G. (2019). Bronzkori kincsek Magyarországon. Földbe rejtett fegyverek, eszközök, ékszerek nyomában. Hereditas Archaeologica Hungariae 3. Budapest: Archaeolingua.

Wanzek, B. (2002). Zur Syntax der Muster auf Griffzungensicheln im bronzezeitlichen Südosteuropa. European Archaeology - Online, http://www.archaeology.ro/pagini/revista_EA_9.html (Letöltés: 2020.11.03.)

Woodward, A. M. (1929). Inscriptions. In R. M. Dawkins (ed.), The Sanctuary of Arthemis Orthia at Sparta (pp. 285-377). The Society for the Promotion of Hellenic Studies, Supplementary paper 5. London: MacMillian \& Co. 